\title{
PSYCHOPHYSIOLOGICAL \\ AND MUSICAL-PSYCHOLOGICAL ASPECTS \\ OF PREPAREDNESS OF PRESCHOOL CHILDREN TO INSTRUMENTAL MUSIC EDUCATION
}

\section{Stashevska I. O.}

\section{INTRODUCTION}

One of the most pressing problems of modern society is the early development of the child's potential. It is the period from the birth to five years old that is crucial for the whole future life of a child: who it will become, what it will be interested in, what abilities it will discover - is mainly determined by this period of life. Up to the age of five, children have the unique ability to learn, and they can learn anything you want, if they are trained in the right form. However, according to psychologists, in the future, this easiness of information assimilation is gradually lost ${ }^{1}$.

The early development of children is considered today in society as a factor in raising people's spiritual and intellectual potential. For this purpose, special kindergartens, research institutes, associations are being created in different countries of the world, various methods of early learning in swimming, gymnastics, reading, mathematics, foreign languages, arts, playing musical instruments and more are being developed.

According to the results of neurophysiological studies, it is known that our brain consists of two interconnected hemispheres that have their functional specialization: the left hemisphere is responsible for the analytical process of thinking, language, writing, numbers, etc.; and the right one - for a holistic process of perception, spatial, nonverbal ideas,

\footnotetext{
${ }^{1}$ В. Кантан. Раннее обучение и развитие ребенка : методики Масару Ибука и Г. Домана. СПб. : Лань, 1998. $64 \mathrm{c}$.
} 
understanding of language, musicality. However, the full functioning of the brain, the balance of all mental processes is ensured by equal and coordinated interaction of both hemispheres ${ }^{2}$.

In this regard, the musical activity of people and their musical education are of particular importance. According to the latest neurobiological and neurophysiological research, the perception of the melody is carried out to a greater extent by the right hemisphere and the rhythm - by the left. This means that music simultaneously activates the work of both hemispheres, resulting in musicians have a better consistency of interaction between two hemispheres of the brain. With this phenomenon, researchers explain the fact of long-term activity of people closely associated with music activities ${ }^{3}$.

It is difficult to overestimate the value of the initial period of the younger generation musical education, because the basic structures of personality are laid in early childhood. Problems of musical education of preschool children attracted the attention of many prominent personalities of the past, as well as progressive scholars and educators of the present (J.A.Comenius, J.-J. Rousseau, J. Pestalozzi, F. Fröbel, B. Asafyev, N. Vetlugina, L. Vygotsky, N. Ganoshenko, J. Dillenkofer, I. Dzerzhinskaya, F. Domke, G. Fischer, L. Friedemann, M. Gellrich, H. Gembris, E. Gordon, P. Heilbut, D. Kreusch-Jacob, M. Küntzel-Hansen, V. Kon, K. Minkevichus, M. Nilson, G. Noll， J. Ribke, S. Suzuki， O. Szende, B. Teplov, M. Trubnikova, N. Folomieieva, V. Shatska, N. Chycherina, etc.).

At the same time, due to the society's awareness of the multifunctional importance of musical art in the personality development, in particular, the positive impact on the spiritual, emotional, intellectual and general physical development of a child from an early age, the problem of preschool children musical education still does not lose relevance and needs further development.

\footnotetext{
${ }^{2}$ Воробьёва Е. А., Губар А. В., Сафьянникова Е. Б. Анатомия и физиология. М.: Медицина. 1988. C. 362 .

${ }^{3}$ Bastian H. G. Kinder optimal fördern mit Musik. Mainz: Schott. 2001. S. 38.
} 


\section{Psychophysiological features of the development of preschool children as a key guideline for forming a pedagogical strategy for their musical and instrumental education}

For thousands of years, people have used the musical instrument as a means of expression along with singing and dancing. But traditionally playing a musical instrument was not considered a child's activity for a long time. Nowadays, thanks to the efforts of progressive scholars and practitioners, musical and instrumental education of preschool children is an important component of the cultural paradigm of the developed countries of the world.

Unfortunately, even with a strong initial desire to play music, it can often be observed that after the first lessons related to playing the instrument, children enthusiasm disappears. Not all children endure the first year of study. The complexity of mastering the instrument discourages children from playing music. Therefore, the central task of the preschool period of musical education is to awaken and keep the desire to play in the child.

A prerequisite for achieving the effectiveness of musical and educational activities is the development of pedagogical strategies taking into account the psychophysiological features of preschool children development.

As it is known, the thinking of a child of preschool age is based on the reflective forms of mental activity - feeling and perception. As they grow older, another form of intellectual activity, the imagination, becomes more and more important. Scientists characterize the imagination as "a generalized dynamic image of reality, which is formed during the dialectical process that takes place in the psyche beyond direct contact with what is imagined..." . Based on some information about the world, our imagination is able to create even such ideas that are unmatched in reality. In such a way the real and inner worlds of the child are intertwined.

\footnotetext{
4 Раппопорт С. О вариантной множественности исполнительства. Музыкальное исполнительство. № 7. М.: Музыка. 1972. С. 18.
} 
Imagination and fantasy play a paramount role in its thought process. Given the peculiarities of child psychology, one should not detach the teaching of playing a musical instrument from the child's habitual existence in the world of fairy tales and games.

Already after the age of three, the child's thinking is sufficiently developed to understand the simplest cause and effect relationships and dependencies, provided that they are presented in a visual form. The visual-acting, visual-figurative, and by the age of five, verbal-logical thinking begins to function. This is the age of curiosity that encourages a child to research and experiment. There is an intense development of self-awareness, the ability to manage their feelings and behavior. Despite the fact that the willed qualities of preschoolers are not yet sufficiently developed, the vast majority of children are able to show willpower efforts to achieve a certain goal, provided that the goal is close and clear to them, and the actions evoke strong emotions. By the age of five, the ability to determine the purpose of future activity and ways to achieve it, the ability to self-control the process of their own work and its end result are formed. All this creates conditions for the successful start of a variety of musical, including musical and instrumental activities of the child.

Children's thinking does not work abstractly, but specifically and visually. Above all, the child perceives what has interested and amazed it emotionally. The most important feature of children's perception is the low ability to differentiate the individual properties of the perceived object, in connection with which the child also experiences the music integrally and without proper training differentiates between the individual musical parameters.

As it was already noted, at the age of $3-5$, a child is in the world of its fantasy and the main type of activity is a game in which not only previously accumulated life experiences are reflected, but also the need for self-expression and further knowledge of the world are satisfied. At about 4 years old, the child's game takes on new forms. A special role is played 
by a thematic or plot-role-playing game in which the child peculiarly reproduces all that it watches. Therefore, such a game is imitative. The instrumentalist must take into account the fact that the motivation of the child's play for the child is the process of action itself, as opposed to the adult, who is more interested in the result of their work. However, in the learning process, the interest of the child is increasingly directed towards the achievement of the result of its own activity, which is an important factor for successful learning of playing a musical instrument: the child seeks for an acceptable acoustic result of its play, feels joy from the performed music, etc.

In addition to gaming, other activities begin to develop gradually: artistic, labor, educational. In the third year of life there is a growing desire for independence, which is more manifested in imitation; that is why in the process of teaching preschoolers to play the instrument, such an important role is given to the child's independent activity, visual and illustrative teaching method.

An important task in the process of musical-instrumental upbringing of a child is the development of its artistic and figurative thinking, which occurs, first, through the formation of the ability to associate certain music with specific semantic images and feelings, that is, the ability to its aesthetic perception, and, second, by developing the abilities and skills of reflecting reality and the inner world in music through the means of musical creativity.

The primary condition for accomplishing this task is "forming connections between associative ideas and patterns of musical embodiment of figurative-semantic phenomena", that is, combining figurative thinking of a child with its performing skills. Obviously, this task is modified and complicated in accordance with increasing the child's level of development, and such development methods of figurative-associative

\footnotetext{
5 Дьяченко Н., Котляревский И., Полянский Ю. Теоретические основы воспитания и обучения в музыкальных учебных заведениях. К.: Муз. Україна. 1987. С. 56.
} 
thinking, such as verbal expressions, clarity, comparison, variability ${ }^{6}$, remain unchanged throughout the learning. Only the methods of their embodiment change.

At preschool age, a child already has a certain stock of imaginative ideas that have been influenced by external stimuli from its past experience and are related to its life, nature, its own emotional experiences, movement feelings and musical impressions. Different types of ideas are linked into associative chains. Each of the impressions can cause the following one. Therefore, the initial development process of the expressive capabilities of the instrument should be based on the imaginative association of the motor, visual, acoustic, tactile and spatial impressions of children accumulated in their memory.

There are subject, emotional and artistic associations. It is the artistic associations that connect the system of artistic means, techniques and structures with the vital, subject and emotional associations ${ }^{7}$. When performing a piece of music, the types of associations are intertwined and complement each other in the mind of a child with a well-developed figurative-associative sphere, one figurative-associative association causes another one.

The word and the verbal description of music have an irreplaceable influence on the formation of artistic and figurative thinking of the child. Undoubtedly, it is impossible to study without timing. But specific concepts must be explained to the child in a language in which abstract designations by means of imaginative pedagogical language acquire a meaningful color, "inspiration". Figurative expressions are very attractive to the child and are crucial in the development of its interest in music. Dry terminology and a stereotypical schematic method of expression are far from living child's perception. A vivid representation of a musical image allows them to select the necessary means of expression, find a way of

\footnotetext{
${ }^{6}$ Ражников В. Г. Резервы музыкальной педагогики. М.: Знание. 1980. С. 12-15.

7 Раппопорт С. О вариантной множественности исполнительства. Музыкальное исполнительство. № 7. М.: Музыка. 1972. С. 18.
} 
sound-forming, articulation, dynamic hues, etc., characteristic for this image, to translate it into real sound. Figurative comparisons and analogies can be found in various fields of environmental reality: in everyday life, in nature paintings, in related arts, especially in children's literature, etc.

Imitation ability is a rich source for preschooler learning activities. For example, when playing musical puzzles, when the teacher performs various sound-tracing techniques on the instrument, and the student finds an appropriate image, the child has a natural desire to try to represent something itself. Playing "echo", the student can repeat after the teacher to imitate the sounds of different animals, birds, musical instruments, etc.

Obviously, it is difficult for a young child to come up with a sound story itself. To facilitate such a task, it is advisable for the teacher, together with the students, to draw up a kind of vocabulary of the simplest rhythmic and articulatory models, onomatopoeic effects. Parents can help making cards with graphic images of performing techniques and small artistic illustrations that children can draw on their own.

Attempts to make a musical embodiment of contrasting musical images are useful. In the form of questions, the teacher can stimulate the child's ability to make comparisons, for example: what sounds short (rain drops) and longer (phone bell), sounds quieter at first, and then louder (approaching plane noise), etc. Pictures from children's books, images of household scenes, pictures of nature will serve as a clear example. Visual examples related to tactile sensations (stroking or light hitting the arm, touching something cold, fluffy, prickly, etc.) and the analogies between them and the nature of sound production on the instrument are often effective.

The development of figurative-associative thinking, in close connection with mastering the material of elementary music, logically leads the student to a conscious mastery of a basic arsenal of expressive means of an instrument that can be successfully used for the development of improvisation skills soon after the beginning of the lessons. 
With the help of already known game techniques children can improvise musical tales and record them graphically. The search for images and means of expression is entirely dependent on the fantasy and imagination of the teacher. However, the lesson should become not only the creativity of the teacher, but first of all - their co-creation with the student. The ability to bring a young musician to their own discoveries is valuable. Identifying their initiative, expressing their own judgment, as well as their questions is indicative of a proper approach by the teacher. It should be borne in mind that the ability to express themselves verbally depends on the type of the child's character, its general cultural level, vocabulary, and the degree of emotional perception.

Particularly important for the development of the child is the communication with peers. Already at preschool age, there is a need for recognition and self-affirmation, and a sense of self-esteem, which is often manifested in increased vulnerability. In this connection, it is of particular importance to combine the group and individual forms of learning to play a musical instrument.

Alternating and skillfully planning individual and group lessons allow to solve many professional problems more successfully. The child is more likely to learn at a group lesson the content of some training lessons, such as mastering the formulation of a playing apparatus, the basics of ensemble music, rhythmic and intonational elements of music related to the use of such methodical techniques as rhythmic pattern subtexting, melody singing, use of rhythmic movements, improvisation on the instrument, etc. For work on musical-artistic expression and technical improvement of a piece of music performance, pair lessons are more suitable. Individual lessons are needed to address the individual problems of each student, as well as the initial phase of developing a new work.

Group form of instrumental music education gives the possibility to find suitable motivation for children's interest in work, which prevents the occurrence of motivational crisis in students, especially at the initial stage 
of mastering the difficulties of instrumental performance. For very small "musicians" it will be, first of all, a game and communicative motivation. The motive for achieving quality performance can be a moment of competitiveness, a desire to demonstrate them and be better than others. Watching and analyzing the play of other students, the child draws conclusions and tries not to repeat the mistake made by another.

Child's comparing of its achievements with the performance of other children creates the conditions for the formation of the ability to adequately evaluate their own actions and quality of performance. In the process of group music, its performing fantasy and imagination are activated. In addition, working in a group contributes to the formation of students' communication skills: the ability to listen to a partner, adhere to the rules of the game, the ability to respond to optical and acoustic instructions, the ability to manage the group through similar signs, as well as stabilize democratic relations between peers. Collective musical creativity can help children to overcome the timidity and anxiety of the audience, which is an important factor for successful performance on the concert stage in the future.

Communication with adults is also equally important for the child, whose love and respect become a guide for its behavior and a necessary stimulus for self-improvement. Working with preschoolers requires special attention and patience from the teacher, because the nervous system of a child under 6 years old is still very unstable.

A huge role in maintaining positive motivation is played by the teacher's communication culture with the student. The harmonious development of the child's personality is promoted by the democratic style of communication of the teacher with the student, characterized by the following features by V.Petrushyn: recognition of the right to independence of judgment and promotion of such independence; building educational work on encouragement and stimulation, not on the threat of punishment; the desire to form a high self-esteem and belief in their own 
strength, which excludes humiliating mockery, remarks, irritability and intolerance; the teacher's desire to unite their students in a team, that's why the successes of some are not put in harm with others and the students are not opposed to each other; the teacher's ability to project tomorrow's personality of their student based on their existing inclinations ${ }^{8}$.

The prerequisite for the lessons is dynamism. However, great attention should be paid to assessing the physical and mental state of the child: general fatigue, loss of interest, decreased reaction rate, lack of concentration, etc. Particularly at an early stage of education, overwork and overload of children are unacceptable, which may cause them to be reluctant to continue their studies.

Not only age, but also individual characteristics of each student should be the subject of special attention of the teacher-instrumentalist. Thus, children differ in gender, character, temperament, life experience, attitude to people and themselves, ability to express their thoughts verbally, the level of cognitive processes (feeling, perception, memory, thinking, imagination, and attention), etc.

The preschool age is an era of versatile motor activity, intensive search for precise, coordinated actions. By the age of five, the child's movements become more sophisticated, psychomotor coordination is improved. According to psychologists, since the age of 4-5, most children, without much difficulty, master the asymmetrical movements of the hands, isolated movements of the fingers, which is the basis for the development of instrumental techniques.

The quality of the musician's performance is directly linked to the production of precise muscular and spatial sensations. The naturalness and expediency of the movements is the most important means of achieving the creative freedom of the performer. The main problem in building a musical instrumentalist's playing apparatus is to determine the limit of muscle tension and the ratios of different muscle conditions during the play.

\footnotetext{
${ }^{8}$ Петрушин В. И. Музыкальная психология. М.: Владос. 1997. С. 301.
} 
Muscle feeling is "a "mediator" between hearing and sound", that's why from the very beginning of musical instrumental education it is necessary to promote the constant development of the ability to control muscle tension and relaxation, to choose the optimal state depending on the playing situation, to use the least possible degree of activity "through constant self-liberation" $" 10$.

Prevention and rescue from excessive muscle tension is one of the main problems of instrumental pedagogy. On the one hand, tightness does not allow achieving the necessary performance result, and on the other hand, prolonged over-tension (chronic muscular tightness) leads to serious occupational diseases.

This is especially dangerous in the preschool period of musical and instrumental development. Negative emotions from mental and physical stress during exercise can awaken in the child an instinctive reluctance to engage not only playing the instrument, but also music in general.

Most often, the excessive muscle tension of the child occurs in the following situations: the child is tired, upset, afraid to make a mistake, holds its breath, holds the instrument uncomfortably; the force of finger pressure on the fingerboard grows with increasing loudness and emotional arousal; as the tempo increases, not only the playing muscles, but also not playing ones, is noticeable, etc.

The only ways to overcome muscular tightness is a control of the actions and an instant relaxation of tight muscles in the process of performing.

The other extreme of the muscle condition is over-relaxation (most commonly found in children at the age of 3-4) that prevents movements that require a certain muscle tone. Strengthening of muscles and development of joints flexibility will help the child in development of the differentiated feeling of muscular condition.

\footnotetext{
${ }^{9}$ Кюхлер Ф. Техника правой руки скрипача. К.: Муз. Україна. 1974. С. 30.

${ }^{10}$ Штейнгаузен Ф. О физиологии ведения смычка. М.: Музторг. 1930. С. 36.
} 
The development of the necessary motor skills is facilitated by various gymnastic exercises. Therefore, the obligatory element of the first lessons in the class of "special instrument" should be gymnastic exercises for the formation of spatial-motor sensations, the development of muscular freedom, plasticity, coordination, reactivity, agility of movements, fine and large motor skills, firmness and strength of the fingers. Despite the fact that the child's movements look awkward at the beginning, its motor skills, reaction abilities under the appropriate conditions are rapidly developing.

When choosing gymnastic exercises, it is necessary to adhere to the following principles: to start with the motor combinations familiar to the child in daily life; to go from large movements to smaller ones; to exercise in the form of games; all gymnastic exercises should prepare for the specific motor functions necessary for further training. It is advisable to perform preparatory gymnastic exercises in a rhythmically organized form.

According to psychological research, "motor sensations are related to the memory of the muscles of any actions performed and their brain memorization in the form of neural traces" $"$. Therefore, when preparing a preschooler to master elementary game movements, one should rely on their previous experience of balancing, relaxing, falling, etc., based on various motor-game activities: swimming, cycling, sledding, riding on a carousel, etc.

An important feature of preschoolers is their poor ability to perform a series of actions only on verbal instructions without showing the example before or after. According to the results of experimental studies, only $10 \%$ of children from 3 to 4 years old can do this, $51 \%$ from 4 to 5 years old, and $84 \%$ from 6 to 7 years old ${ }^{12}$. Movement, like any other information, is easier for children to learn through a visual example than through a verbal explanation. However, when shown with verbal guidance, motor skills are formed more successfully, require fewer repetitions, and are characterized

\footnotetext{
${ }^{11}$ Петрушин В. И. Музыкальная психология. М.: Владос. 1997. С. 150.

12 Szende O. Zur Didaktik und Methodik der instrumentalen Früherziehung. Mit Beispielen aus dem Geigenunterricht. Wien: Universal Edition. 1981. S. 43.
} 
by fewer mistakes than with a silent showing ${ }^{13}$. Thus, the indispensable unity of verbal and visual-illustrative teaching method is of particular relevance in the development of preschoolers' skills in playing the instrument.

\section{Features of musical development of preschool children in view of their preparedness for instrumental music education}

The development of a child's musicality depends on two major factors: the genetically determined maturation of language and acoustic centers of the brain, as well as the environmental impact. Numerous studies have shown that the maturation of these centers is incomplete if there is no permanent external influence on the organs of perception In E. Gordon's theory of teaching, which underlies the developmental psychology, there is a statement that all people appear in the world with absolute hearing and a sense of rhythm, which creates the most important prerequisites for musical development. However, if innate abilities are not developed, they gradually disappear ${ }^{14}$.

Musical development of the child is carried out in three stages: unconscious perception, more or less meaningful perception and gradual transition to conscious musical activity. The basis of forming the ability of musical perception is the communication of a person with music, which should begin at the earliest stages of its existence.

Experimental research in the field of psychology and developmental physiology proves that the child's auditory perception begins even before the birth. The human embryo is able to perceive and differentiate external acoustic stimuli: not only noise, but also sound level, rhythm of spoken language and music. Hearing organs and the vestibular apparatus that begin to function at the age of 4.5 months are responsible for this activity ${ }^{15}$.

\footnotetext{
${ }_{13}^{13}$ Воспитание детей дошкольного возраста. Ред. Л. Н. Проколиенко. К.: Рад. шк. 1990. С. 326.

14 Müller K. Vorschulerziehung und Frühpädagogik. Musik im Vorschulalter. Dokumentation der Studientagung ,Musikalische Früherziehung. Regensburg: Bosse. 1974. S. 20.

15 Tomatis A. Der Klang des Lebens. Vorgeburtliche Komunikation - die Anfänge der seelischen Entwicklung. Reinbek: Rowohlt. 1987. S. 61.
} 
Moreover, the impressions of the acoustic signals are delayed in its memory, and even in the first days after birth, the child is able to recognize the verses or musical passages that were often heard before. The infant is known to distinguish the mother's voice from other voices, but it can also distinguish the sound and rhythmic specificity of the language spoken by its mother from meaningless component sequences, as well as from other languages (e.g., distinguish German from English, French, etc.) ${ }^{16}$.

M. Gellrich states that important stages of a child's musical development also begin before their birth and in the early years of life, and any kind of mother's musical activity during pregnancy directly affects the musicality of the baby's future. The more powerful the influence, the more prominent it is when singing or playing a musical instrument. The embryo is particularly receptive to the sounds of violin, guitar and cello - instruments that have a rich overtone sound spectrum. In addition, sound resonance is transmitted through direct contact of the instrument with the mother body ${ }^{17}$.

Approximately 2 months after birth, the baby's vocalization begins to develop. A crucial role in this process is played by non-verbal communication of the infant with the environment: it imitates the melody of speech $^{18}$.

Being aware of the system of musical symbols as a kind of language, for which development it is necessary to pay as much attention as for the development of the mother tongue, scientists come to the belief - music teaching of children of early preschool age can be carried out similar to the teaching of their mother tongue. This is possible provided that the child between two and five years old hears a lot of music ${ }^{19}$. It is worth considering

\footnotetext{
16 Tomatis A. Der Klang des Lebens. Vorgeburtliche Komunikation - die Anfänge der seelischen Entwicklung. Reinbek: Rowohlt. 1987. S. 14-16.

17 Gellrich M. Musikalitätsförderung im vorgeburtlichen Stadium und im Kleinkindalter. Musikalische Bildung in Zwischenräumen. Symposiumbericht Musikalische Früherziehung/ Grundausbildung. Hamburg 1992. Mainz: Schott. 1993. S. 60.

${ }^{18}$ Gembris H. Entwicklungspsychologie musikalischer Fähigkeiten. Kompendium der Musikpädagogik. Kassel: Bosse. 1995. S. 314.

${ }_{19}$ Gellrich M. Musikalitätsförderung im vorgeburtlichen Stadium und im Kleinkindalter. Musikalische Bildung in Zwischenräumen. Symposiumbericht Musikalische Früherziehung/ Grundausbildung. Hamburg 1992. Mainz: Schott. 1993. S. 55-70; Steinschaden B., Zehetmar H. Hören und Geigen nach Suzuki. Eine Anleitung aus europäischer Sicht. Wilhelmshaven: Heinrichshofen. 1982. 61 s.
} 
that musical works should be repeated frequently, as well as paying special attention to the quality of music and the choice of musical style.

Developmental psychology points to the phenomenon of acceleration, which is expressed in the accelerated physical and mental maturation of the child: the degree of general development of the modern preschooler is much higher than it was a few decades ago. The results of experimental studies of the child's musical abilities indicate that already at preschool age, children have abilities that are not used in their musical development, so it is not intense enough. By the age of $4-5$, children have sufficient intonation and hearing experience, which is formed both in the conditions of purposeful actions in the family, kindergarten, etc., and spontaneously under the influence of the surrounding sound environment. For example, when creating the necessary pedagogical conditions, children of 3-4 years old will learn the simplest singing skills and be able to sing a small song on their own or with the help of an adult ${ }^{20}$, at the age of 4-5, many children can determine the overall mood of the music and even genre features (song, dance, march) ${ }^{21}$, as well as they have an elementary sense of musical form, ability of harmonious and even timbre hearing: $97 \%$ of fiveyear-olds recognize the sound of the trumpet, 93\% - the violin, 96\% - the piano $^{22}$. Already at the age of five most children have a fairly high level of development of rhythmic and melodic memory, determined by a stock of visual, auditory, emotional, motor impressions.

Empirical studies of the elements of a child's musical competence in early childhood provide a basis for justifying the use lawfulness of any kind of musical activity in the process of its musical education. H. Gembris, on the basis of English and German-language publications of the last decades of the twentieth century in the field of musical development psychology, classifies the ability to musical perception of a child according to the age stages of its development:

\footnotetext{
${ }^{20}$ Ветлугина Н. А., Кенеман А. В. Теория и методика музыкального воспитания в детском саду. М.: Просвещение. 1983. С. 90.

${ }^{21}$ Психология музыкальной деятельности: Теория и практика / Под ред. Г. М. Цыпина. М.: Академия. 2003. C. 218.

${ }^{22}$ Michel P. Psychologische Grundlagen der Musikerziehung. Leipzig: Breitkopf/Härtel. 1975. S. 98-102.
} 
- 0-6 months: prefers musical sounds to other noises; distinguishes high and low, loud and quiet sounds, as well as rhythmic changes and melodic transposition in another tone; voice range covers about 2 octaves;

- 6-12 months: distinguishes a musical phrase from a messy set of sounds;

- 1-2 years old: the child is capable of short-term synchronization of rhythm and movement; distinguishes between high, medium and low sounds; recognizes familiar tunes;

- 3-4 years old: distinguishes between fast and slow pace; major as cheerful and minor as sad tonality; determines the character, emotional imprint (joy, sorrow, rage, fear, etc.) of the melody in harmony and tempo;

- 5-6 years old: distinguishes the sound of different instruments, even within the same family (for example, violin, cello, contrabass); distinguishes between tone and semitone; notices modulations in other tonality; feels tonic; capable of symbolic representation of melody and rhythm; distinguishes consonance from dissonance, tone from atonality, rhythmic organization from arrhythmic ${ }^{23}$.

The results of modern psychological research indicate that in the fourth year of life in most children there is a significant progress in the development of musical and auditory abilities. The ability to reproduce a melody pattern relatively correctly is formed in most children between the ages of four and $\operatorname{seven}^{24}$. Scientists note that at the age of 5 , children can reproduce two components of the rhythm structure: tempo and metric pulsation, and at the age of 6-7 - all three: tempo, meter and rhythmic pattern of adequate complexity. The sense of musical rhythm develops in children by learning the system of music-rhythmic standards. At the initial stage of a child's musical development, psychologists recommend using duple, triple, and quadruple meters as the simplest standards of a musical

\footnotetext{
${ }^{23}$ Gembris H. Entwicklungspsychologie musikalischer Fähigkeiten. Kompendium der Musikpädagogik. Kassel: Bosse. 1995. S. 317-320.

24 Психология музыкальной деятельности: Теория и практика. Под ред. Г. М. Цыпина. М.: Академия. 2003. C. 171 .
} 
meter and as tempo standards - slow, moderate, and fast. Moreover, at first the children master the standard of fast tempo, then - moderate, and approximately at the turn of 6-7 years old they acquire the ability to perceive and reproduce the slow tempo. The process of comprehending the size ranges from duple to triple meters, and the rhythmic pattern - from mastering simple "square" schemes to more complex ones ${ }^{25}$.

A variety of musical activities are the means of musical development. Therefore, the content of lessons aimed at instrumental music education of preschoolers should include not only the development of instrumental playing skills, but also such types of musical activity of the child as listening to music, singing, acoustic experiments, language recitation, musical-rhythmic movement, elemental composition and improvisation, ensemble music, elements of musical theater.

Integration of various types of musical activity in the lesson will allow providing efficiency of development of artistic and figurative thinking, fantasy and imagination, auditory and motor coordination, internal musical representations, melodic, harmonious, timbre, dynamic hearing and sense of the rhythm of a child, formation of its musical intellect, fundamental staging and performing skills.

\section{CONCLUSIONS}

Thus, based on the results of researches in the field of psychology of general and musical development of the child, statistical analysis, experience of music-pedagogical practice of different countries of the world, it can be argued that physical strength, differentiation of sensory organs, motor and mental abilities, as well as the level of musical development, an ordinary child of 4-6 years old is allowed to carry out with it systematic lessons on mastering of performance elements on classical musical instruments (piano, violin, small guitar, block flute, etc.) and, moreover, the age of 4-6 is defined as the most favorable for starting

\footnotetext{
25 Психология музыкальной деятельности: Теория и практика. Под ред. Г. М. Цыпина. М.: Академия. 2003. C. $155-156$.
} 
such classes. In addition, according to the results of scientific research and music-pedagogical practice, with the use of game forms of teaching and taking into account the age and individual characteristics of students, preschoolers do not lag behind school-age children and some of them develop even more intensively.

An important condition for ensuring the quality of preschoolers' instrumental music education is the integration in the activities content of different types of children's musical activity, which contributes to the formation of the beginner's ability to make meaningful, aestheticallyoriented perception of music, creative desire to reflect the surrounding reality and own inner world in sounds, and education of creative, spiritually developed personality from early childhood.

\section{SUMMARY}

Psychophysiological and musical psychological aspects of the preparedness of preschool children to instrumental music education are investigated in the work. The multifunctional importance of musical art in personality development is emphasized. The recommendations on formation of pedagogical strategy of instrumental music education taking into account psychophysiological peculiarities of children's development of preschool age are offered. Possibilities of development of artistic and figurative thinking of a child by forming in it the ability to associate certain music with specific semantic images and feelings and development of abilities and skills of real reality reflection and own inner world in music by means of musical creativity are characterized. The importance of combining group and individual forms of teaching preschoolers playing musical instrument is revealed. The peculiarities of musical development of preschool children in terms of their readiness for instrumental music education are analyzed. It is proved that physical strength, differentiation of sensory organs, motor and mental abilities, as well as the level of musical development of an ordinary child at the age of 4-6 allow to carry out with it systematic lessons on 
mastering the elements of performance on classical musical instruments. It is stated that an important condition for ensuring the quality of instrumental music education of preschoolers is the integration in the content of various types' classes of children's musical activity.

\section{REFERENCES}

1.В. Кантан. Раннее обучение и развитие ребенка : методики Масару Ибука и Г. Домана. СПб.: Лань. 1998. 64 с.

2. Ветлугина Н. А., Кенеман А. В. Теория и методика музыкального воспитания в детском саду. М.: Просвещение. 1983. 255 с.

3. Воробьёва Е. А., Губар А. В., Сафьянникова Е. Б. Анатомия и физиология. М.: Медицина. 1988. 432 с.

4. Воспитание детей дошкольного возраста. Ред. Л. Н. Проколиенко. К.: Радянська школа. 1990. 368 с.

5. Дьяченко Н., Котляревский И., Полянский Ю. Теоретические основы воспитания и обучения в музыкальных учебных заведениях. К.: Муз. Україна. 1987. 111 с.

6. Кюхлер Ф. Техника правой руки скрипача. К.: Муз. Україна. $1974.59 \mathrm{c}$.

7. Петрушин В. И. Музыкальная психология. М.: Владос, 1997. 384 c.

8. Психология музыкальной деятельности: Теория и практика. Под ред. Г. М. Цыпина. М.: Академия. 2003. 368 с.

9. Ражников В. Г. Резервы музыкальной педагогики. М.: Знание. 1980. 96 c.

10. Раппопорт С. О вариантной множественности исполнительства. Музыкальное исполнительство. Bыл. 7. М.: Музыка. 1972. С. 3-46.

11. Штейнгаузен Ф. О физиологии ведения смычка. М: Музторг. 1930. 107 c.

12. Bastian H. G. Kinder optimal fördern mit Musik. Mainz: Schott. 2001. $108 \mathrm{~s}$. 
13. Gellrich M. Musikalitätsförderung im vorgeburtlichen Stadium und im Kleinkindalter. Musikalische Bildung in Zwischenräumen. Symposiumbericht Musikalische Früherziehung/ Grundausbildung. Hamburg 1992. Mainz: Schott. 1993. S. 55-70.

14. Gembris H. Entwicklungspsychologie musikalischer Fähigkeiten. Kompendium der Musikpädagogik. Kassel: Boss. 1995. S. 281-332.

15. Michel P. Psychologische Grundlagen der Musikerziehung. Leipzig: Breitkopf/Härtel. 1975. 175 s.

16. Müller K. Vorschulerziehung und Frühpädagogik // Noll G., Suder A. Musik im Vorschulalter. Dokumentation der Studientagung „Musikalische Früherziehung“. - Regensburg: Bosse, 1974. S. 15-21.

17. Steinschaden B., Zehetmar H. Hören und Geigen nach Suzuki. Eine Anleitung aus europäischer Sicht. Wilhelmshaven: Heinrichshofen. 1982. $61 \mathrm{~s}$.

18. Szende O. Zur Didaktik und Methodik der instrumentalen Früherziehung. Mit Beispielen aus dem Geigenunterricht. Wien: Universal Edition. 1981. $143 \mathrm{~s}$.

19. Tomatis A. Der Klang des Lebens. Vorgeburtliche Komunikation - die Anfänge der seelischen Entwicklung. Reinbek: Rowohlt. 1987. $304 \mathrm{~s}$.

\section{Information about the author:} Stashevska I. O.

Doctor of Pedagogical Sciences, Professor, Honored Art Worker of Ukraine, Vice-rector for Educational Work, Kharkiv State Academy of Culture 4, Bursatskyi uzviz, Kharkiv, Ukraine 